\title{
Raffaele Morabito, Situazioni e soluzioni da Balzac a Pirandello
}

\section{Marco Stupazzoni}

\section{Q OpenEdition \\ 1 Journals}

\section{Edizione digitale}

URL: http://journals.openedition.org/studifrancesi/33391

DOI: 10.4000/studifrancesi.33391

ISSN: 2421-5856

\section{Editore}

Rosenberg \& Sellier

\section{Edizione cartacea}

Data di pubblicazione: 1 décembre 2005

Paginazione: 659

ISSN: 0039-2944

\section{Notizia bibliografica digitale}

Marco Stupazzoni, «Raffaele Morabito, Situazioni e soluzioni da Balzac a Pirandello», Studi Francesi [Online], 147 (XLX | III) | 2005, online dal 30 novembre 2015, consultato il 18 avril 2021. URL: http:// journals.openedition.org/studifrancesi/33391 ; DOI: https://doi.org/10.4000/studifrancesi.33391

Questo documento è stato generato automaticamente il 18 avril 2021.

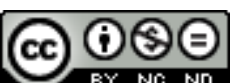

Studi Francesi è distribuita con Licenza Creative Commons Attribuzione - Non commerciale - Non opere derivate 4.0 Internazionale. 


\title{
Raffaele Morabito, Situazioni e soluzioni da Balzac a Pirandello
}

\author{
Marco Stupazzoni
}

\section{NOTIZIA}

RAFFAELE MORABITO, Situazioni e soluzioni da Balzac a Pirandello, in AA.VV., Sylva. Studi in onore di Nino Borsellino, a cura di Giorgio PATRIZI, Roma, Bulzoni editore, 2002, pp.

707-715.

1 Per quanto distanti tra loro siano i principî e i percorsi letterari assunti e intrapresi da Balzac e da Pirandello, non è del tutto fuori luogo tentare di stabilire (pur con tutta la prudenza del caso) alcune affinità tematiche presenti nell'opera dei due scrittori, anche in considerazione del fatto che il nome di Balzac è presente in misura rilevante $\mathrm{e}$ significativa nel catalogo della biblioteca pirandelliana.

2 In questo studio, R. Morabito individua la coincidenza di taluni temi di fondo riscontrabili negli autori esaminati: anzitutto, l'ossessione del rapporto arte-vita che ritroviamo espressa nel Chef-d'oeuvre inconnu balzachiano e in Diana e la Tuda di Pirandello. In entrambe le opere, scrive l'A., emerge la consapevolezza del fallimento di ogni tentativo artistico di «fissare le forme della vita; e la conclusione del processo, che nella pratica si rivela impossibile, è la morte dell'artista» (p. 710). La seconda coppia di testi sui quali l'A. concentra la sua attenzione riguarda un episodio narrato in Illusions perdues (dove è protagonista Lucien de Rubempré nel ruolo di amante di Mme de Bargeton) che, a suo giudizio, rimanderebbe ad una situazione analoga descritta da Pirandello (ma ancor prima da Verga in Eros) nel Giuoco delle parti e nel suo palinsesto narrativo: la novella Quando si è capito il giuoco. Nella figura di Leone Gala, Pirandello arriva a capovolgere «una situazione che era entrata a far parte di quelle codificate dalla narrativa ottocentesca: il marito che sfida a duello per difendere l'onore offeso d'una moglie la quale lo tradisce» (p. 714). In questo senso, puntualizza l'A., Pirandello 
ci pone di fronte ad «un'immagine capovolta della realtà , rovesciando le convenzioni della tradizione letteraria nel cui solco si colloca» (p. 715). 